\title{
Corruption and Adherence to Rules in the Construction Sector: Reading the "Bidding Books"
}

\section{Sylvia Tidey}

\begin{abstract}
In this article, I explore how anticorruption strategies affected a tender held in 2008 at the Department of Public Works in Kupang, eastern Indonesia, in ways both unexpected and unintended. I show how anticorruption programs get refracted at the local level and become unanchored from their original intention, leading to an obsession with adherence to the form of the anticorruption discourse that runs counter to its spirit and actually undermines the anticorruption initiative by providing new opportunities for corruption. Here I contribute to recent anthropological attention to both corruption and documents by looking at how traces of corrupt procedures can be found in the very documents designed to counter them. I argue that documents form a significant ethnographic point of departure from which to study the unintended effects of anticorruption programs, especially when they perform the ambiguous effect of both strengthening the anticorruption discourse and subverting it. [corruption, documents, Indonesia, construction sector]
\end{abstract}

ABSTRAIT J'enquête dans cet article la manière dont les stratégies de lutte contre la corruption affectèrent un appel d'offres par la Section des Travaux Publiques à Kupang. Je démontre que la réalisation des programmes de lutte contre la corruption au niveau local les détache des intentions qui les motivent à l'origine, ce qui donne lieu à une obsession par la conforme à la forme du discours contre la corruption, qui va à l'encontre de ses intentions originaires et finit par engendrer de nouvelles occasions de corruption, sapant donc l'esprit même de ces initiatives. Je contribue à l'intérêt récent en anthropologie porté sur la corruption ainsi que sur les documents. Je soutiens que les documents constituent une base de départ ethnographique importante pour l'étude des effets fortuits des programmes de lutte contre la corruption, particulièrement quand ils ont l'effet équivoque de renforcer ainsi que de subvertir le discours contre la corruption. [corruption, documents, Indonésie, secteur de la construction]

RINGKASAN Dalam tulisan ini saya mengeksplorasi strategi anti-korupsi mempengaruhi - secara tidak diharapkan dan tidak diinginkan - sebuah tender di Departemen Pekerjaan Umum di Kupang, Nusa Tenggara Timur, pada tahun 2008. Saya memperlihatkan bagaimana program-program anti-korupsi menjadi bias di tingkat lokal dan terlepas dari tujuan awalnya yang mengarah pada obsesi dengan kepatuhan terhadap bentuk wacana anti-korupsi untuk melawan semangatnya dan sesungguhnya memperlemah prakarsa anti-korupsi dengan memberikan peluang-peluang baru bagi tindak korupsi. Saya berkontribusi pada perhatian antropologi akan korupsi dan dokumen dengan melihat pada bagaimana jejak-jejak prosedur yang korup dapat ditemukan dalam dokumen yang dirancang untuk melawan korupsi. Saya berpendapat bahwa dokumen-dokumen membentuk titik berangkat etnografi untuk mengkaji akibat-akibat yang tidak diinginkan dari program anti-korupsi, khususnya ketika mereka memperlihatkan akibat yang ambigu, yaitu memperkuat sekaligus melemahkan wacana anti-korupsi. [korupsi, dokumen, Indonesia, sektor konstruksi] 
RESUMEN En este artículo exploro cómo las estrategias anticorrupción afectaron una licitación que se llevó a cabo en el 2008 en el departamento de Trabajos Públicos en Kupang, Indonesia Oriental, en formas tanto inesperadas como inintencionadas. Demuestro como los programas anticorrupción se refractan a nivel local y llegan a desanclarse de su intención original llevando a una obsesión con la adherencia a la forma del discurso anticorrupción que va en contravía a su espíritu, y que actualmente erosiona la iniciativa anticorrupción a través de proveer nuevas oportunidades para corrupción. Aquí contribuyo a la reciente atención antropológica tanto a la corrupción como a documentos analizando cómo huellas de procedimientos corruptos se pueden encontrar en los documentos diseñados para contrarrestarlos. Sostengo que los documentos constituyen un punto de partida etnográfico significativo desde el cual se pueden estudiar los efectos imprevistos de los programas anticorrupción especialmente cuando ellos cumplen el efecto ambiguo tanto de fortalecer el discurso anticorrupción como de subvertirlo. [corrupción, documentos, Indonesia, sector de la construcción]

Because they [Public Works committee] think we have mistakes [in our administrative package], we cannot enter the tender. Because of matters that are actually small. Even though we have good experience in the field, we have the financial ability, and we have the personnel, we cannot enter. They prioritize the documentation more. We might as well throw our good proposal out the window since surely we will lose. [Interview with author, February 10, 2009]

A contractor made this complaint to me after a tender, a public auction for construction projects, which took place in the fall of 2008 at the Department of Public Works in the eastern Indonesian town of Kupang. Similar to other contractors I interviewed, he lamented the discrepancy between what he thought project committees ought to consider when judging the eligibility of bidding contractors' proposals, such as experience, financial backing, personnel, and the quality of a proposal, and what he found they actually used as reasons to accept or reject proposals, namely small, administrative mistakes. In other words, whereas he assumed that the content of his proposal would take priority over the form of his submitted documentation when competing for construction projects, it appeared that form, in fact, weighed heavier. This preoccupation with adherence to form characterized the bidding processes during the 2008 tender at the Department of Public Works more generally. However, similar to the complaint voiced by this contractor, this following of the form of rules, regulations, and procedures did not mean they were actually carried out. Despite an apparent adherence to rules and regulations, "good relations," "lobbying," and "commitment" mattered more in the bidding competitions than submitting the most competitive proposal.

The existence of informal practices amid formal procedures during a public auction of construction projects is not unique to Kupang, nor to Indonesia. The construction sector is an industry especially prone to corruption (Stansbury 2005). Since the late 1990s, Indonesia has taken serious steps to curb corruption in its construction sector through the implementation of various national and regional anticorruption laws. Nevertheless, despite a rigorous revision of the legal framework surrounding the construction sector and tendering processes, as well as the founding of various anticorruption agencies to audit construction dealings, corruption continues to characterize the construction sector, leading some scholars to ask why corrupt practices persist in Indonesia's construction sector despite stricter policies (Kurniasih and Yuwono 2004; Purwanto and van Klinken 2010; van Klinken and Aspinall 2011). This discrepancy between laws and agencies designed to implement change and the actual, on-the-ground practices is central to this article. Of interest is not the question of why anticorruption strategies have failed. Rather, I ask: If these recent structural changes did not reduce corruption, what effects did they have?

In this article, I therefore discuss how rules, regulations, and laws that aim to reduce corruption in Indonesia's construction sector affected a tender for construction projects that took place in the fall of 2008 in the eastern Indonesian town of Kupang. I argue that procedures to reduce corruption in the construction sector have actually enabled new opportunities for corruption. To make this argument, I will show that to avoid suspicions of "corrupt behavior," contractors and officials display a tremendous preoccupation with maintaining adherence to the form of the new rules and regulations. By "adherence to form," I mean that all aspects of the tender that can be seen, read, and checked (e.g., by auditors) are meticulously carried out in compliance with the new rules and regulations; if what is visible and tangible appears to be in line with the rules, then there is no "proof" to support anticorruption investigations. Office documents - those bureaucratic artifacts from which "corruption" can be read and proved most easily - form a pivotal part of this adherence to the form of rules and regulations, which is why in this article I want to focus in particular on documents and what they do. Office documents display the kind of transparency and competition that anticorruption 
programs advocate and thus maintain the anticorruption discourse as propagated by the World Bank and as codified in Indonesian law. As I will demonstrate, however, documents also ensure a continuation of existing "informal" gift-giving practices and even enable new forms of "corruption" precisely because of their visible adherence to the new rules and regulations. I thus argue that documents can perform the ambiguous effect of both strengthening the anticorruption discourse and subverting it, and therefore they form a significant ethnographic point of departure from which to study the unintended effects of anticorruption programs.

By taking documents, "the most despised of all ethnographic subjects" (Latour 1988:54), as a starting point for an empirical study of how anticorruption programs in Indonesia get refracted at the local level, I hope to add to the emerging interest in documents in anthropology (see Das 2004; Holston 1991; Hull 2008; Poole 2004; Riles 2001). This attention to documents and what they do is particularly interesting in the current conjuncture of increasingly influential international anticorruption programs and their potentially contradictory local effects. Documents namely, on the one hand, carry deceptively convincing Weberian associations as a dominant emblem of bureaucracy on which "the management of the modern office is based" (Weber 1968:67). From this point of view, documents are the "neutral purveyors of discourse" (Hull 2012:253) that spread and consolidate recent anticorruption legislation throughout national and regional bureaucracies in a rational and impartial manner. However, as the growing body of literature on documents as ethnographic artifacts shows, documents are not merely materialized outputs from bureaucratic programs but, rather, are fraught with discrepancies between official and other possible readings (Tarlo 2001), provide opportunities for state functionaries to pursue their own private interests (Hull 2003), or can enable forms of cognition that contrast with bureaucratic reasoning (Riles 2006). In short, documents thus do not always do what they say they do but often do other things.

In what follows, we will encounter various kinds of documents that circulated during the 2008 tender. Of particular interest, however, are the "bidding books" that Public Works provides for every available project. These books consist of a pile of dirtied pages with a few columns on them, kept in a manila folder. In these books, prospective contractors enlist for projects by writing down the name of their company, the name of its owner, a signature of its representative, and the company stamp. On the surface, the bidding books exemplify exactly those objectives stressed in the anticorruption discourse: transparency of the tendering process and competition between contractors. A closer reading, however, reveals certain discrepancies that contradict this discourse. By focusing my analytic gaze on these documents, I will argue that this tremendous importance put on the adherence to the form of this discourse not only allows for a continuation of certain corrupt practices but also enables novel forms of corruption that are inextricably linked to efforts to make the books look good. I thus propose that one "effect" of Indonesia's attempt to curb corruption in its construction sector is an increased importance of adherence to the form of the anticorruption discourse, which becomes particularly marked in documents. But as I will show, the adherence to bureaucratic form that the documents display ambiguously reiterates and emphasizes the anticorruption discourse while also contradicting and subverting it.

\section{CORRUPTION: LEGAL CLARITY AND PRACTICAL AMBIGUITY}

"Corruption" is a contentious topic in Indonesia, as it is in many other places. The reform movement that emerged in the wake of the 1997 Asian financial crisis and that helped oust President Suharto after his 31-year-long reign cohered to a large extent around popular discontent with the rampant corruption perpetrated by Suharto and his cronies. After Suharto's demise in 1998, Indonesia implemented a range of structural measures aimed at changing the institutional framework in which corruption and rent seeking had become so entrenched. These measures were significantly influenced by the IMF's stringent conditions for a financial bailout, which were based on a "good governance" view of combatting corruption as propagated by international agencies such as the World Bank and the United Nations Development Program since the late 1990s and which emphasized the improvement of government discipline (Aspinall and van Klinken 2011). They entailed the introduction of new banking regulations, commercial courts, extended external auditing of government departments, the establishment of anticorruption agencies, and new administrative procedures and regulations concerning procurement and tendering (Robison 2006). ${ }^{1}$ The legal and institutional changes that Indonesia implemented thus reflect conceptions of corruption and ideas on causes of corruption that are currently dominant in international institutions and governments and among policymakers, which are most succinctly expressed in a seemingly straightforward and unproblematic definition of corruption given by the World Bank-as "the abuse of public office for private gain" (World Bank 2001:8).

This definition reflects a structural social science approach favored in the field of international relations, which is "directed more towards analysing the system of formal rules and institutions" and making "corruption" definable, quantifiable, and measurable, which can, for instance, be seen in publications such as Transparency International's Corruption Perception Indexes (Shore and Haller 2005:4). Such an approach lends itself to a "projectization"- the transformation of a virtue into a specific activity called a project (Sampson 2005) — of ideals into anticorruption programs. Such programs help promote the apparent "neutral" neoliberal project of ideals of transparency, efficiency, and accountability: in short, "good governance." However, such claims about corruption and how to fight "it" are accompanied by some uneasy assumptions regarding the neutrality of 
anticorruption initiatives, the culprits in corrupt practices (and those best positioned to battle it), and boundaries between state and society.

With its method of long-term ethnographic inquiry, anthropology has the important task of challenging conceptions of corruption and ideas about the causes of corruption that currently influence structural anticorruption initiatives and legislation, which in turn now impact - in unexpected and contradictory ways - localities such as Kupang. Far from viewing anticorruption as a neutral project toward "good" governance, Steven Sampson instead posits it as a "moral force" (and even "moral crusade") carried out by the "integrity warriors" of Transparency International, which "entails not only making governments or aid programs more effective, but also making people more honest, raising people's consciousness to a new level" (2005:104-105). The view from this moral high ground ignores the fact that anticorruption agencies can be corrupt and that anticorruption programs can be used for contradictory purposes (Sampson 2005).

Nevertheless, Daniel Jordan Smith (2006) (see also Harrison 2006) has argued that anthropology has not concerned itself enough with explicit studies of corruption. He explains this partly by the discipline's longtime focus on smaller-scale societies and anthropology's emphasis on local rationalities and cultural logics. What political scientists would describe as corruption is explained in terms of "gift exchange, moral economies, reciprocity and patronage" (Smith 2006:10). Although a focus on "local rationalities" is important — and is, indeed, something anthropology can contribute to discussions about corruption in general-more emphasis, Smith says, is needed on the entanglement of "cultural logics" with mechanisms of state power, bureaucracy, and policy to challenge the kind of assumptions implicit in the conceptions of corruption that are popular in international policy circles as described above. Portraying "corruption" in terms of (local) cultural logics does little to problematize stereotypes that hold that "corruption" is something of the "Other" - the non-West, outside the rational-legal, neoliberal state, and outside the law.

Although anthropologists have shown some reluctance to engage in debates about "corruption," an increasing number of anthropological studies have emerged over the last decade in which the intersection between corruption, morality, state, and capitalism is addressed more explicitly (see, e.g., Haller and Shore 2005). These studies emphasize the wide range of forms of corruption (Blundo et al. 2006); the embeddedness of patterns of personal relations and gift giving within changing state configurations (Rivkin-Fish 2005; Yang 1994); the frictions between morality and legitimacy (Pardo 2000); how claims to legitimacy are tied to the ability to exercise authority (Harrison 2006); and the wide geographic range of corrupt practices (Pardo 2004) that contradict assumptions that corruption is something belonging to the non-Western "Other" and is incompatible with legal rationality.
In fact, corruption can be found at the heart of the regulated world-capitalist system. For instance, Carol MacLennan (2005) describes the role that kinship, social networks, and socialization strategies play in U.S. corporate culture in her discussion of the Enron scandal. In his study on corruption in the European Commission, Cris Shore (2005) furthermore shows how fraud, nepotism, and cronyism are rather compatible with the legal-rational structures of bureaucracy. To some, the anti-Weberian informal system of administration based on personal networks in the European Union is actually "something to be celebrated" (Shore 2005:138). Thus, even in the heartland of legal rationalitythe European Commission — practices that might be viewed as "corrupt" are fraught with a moral ambiguity that challenges straightforward definitions.

\section{ANTICORRUPTION, FEAR, AND FORM}

As discussed above, the conception of corruption that has influenced Indonesia's recent anticorruption efforts is based on a fairly unambiguous World Bank definition and allows for "corruption" to be quantified, measured, and "combated" through anticorruption programs. From such a point of view, the state-dependent construction industry in Indonesia is certainly a cause for worry. According to Transparency International's measurements, for instance, the construction sector repeatedly emerges as the most corrupt (Transparency International 2008). Construction companies for which the state is the main client, moreover, report particularly high levels of corruption in both "non-Western" (Davis 2004; Ding 2001) and "Western" contexts. ${ }^{2}$ Corrupt practices in government-funded construction projects, nevertheless, seem to be particularly marked in Indonesia, where an estimated 30 percent of the national procurement budget is lost annually to corruption (Transparency International 2009), and 80 percent of the building contractors are dependent on government projects (World Bank 1997). ${ }^{3}$ Therefore, according to measurements of corruption as a quantifiable and clearly defined concept, Indonesia - and its construction sector in particular - is very corrupt.

One solution to combat this has been the strengthening of the weak legal basis underlying the construction business. The legal revisions that particularly aim to do this are articulated in Presidential Decree 80/2003, concerning the improvement of the execution of procurement and the standardization of all regulations on activities related to the procurement of goods and services. ${ }^{4}$ It aims to remove some of the loopholes thought to facilitate corruption and promote a more open, transparent, and competitive tender process. Additionally, two audit bodies came into being that have the specific purpose of auditing the procurement of goods and services: the internal audit body BPKP (Badan Pengawasan Keuangan dan Pembangunan [Development and Finance Surveillance Agency]) and the external audit body BPK (Badan Pemeriksa Keuangan [Supreme Audit Board]).

However, this seemingly unambiguous conceptualization of corruption rests on clear distinctions between public 
and private, state and society, legal and illegal, and moral and immoral that practices in bureaucratic settings do not maintain. For example, Akhil Gupta (1995) has demonstrated that the bureaucratic practices of lower-level officials in North India blur Eurocentric boundaries between state and civil society. "Corruption" is similarly hard to define in Kupang, the town that topped Transparency International's list of most corrupt cities in Indonesia in 2008. Kupang is the capital of the eastern Indonesian province of East Nusa Tenggara (or Nusa Tenggara Timur [NTT] in Indonesian), and it has a population of almost 300,000. In contrast to most of Indonesia, the majority of the population is Christian (Protestant and Catholic), whereas a minority is Muslim. "Nanti Tuhan Tolong" [God will help later] and "Nasib Tak Tentu" [uncertain or unfixed fate] are some of the unflattering nicknames given to the province - and not without reason. East Nusa Tenggara is among the poorest provinces of Indonesia. With regard to economic growth, the eastern part of the archipelago lags behind the development of the western part of Indonesia, resulting in a relatively high dependence on the state instead of other, nonagricultural sources of income. Unsurprisingly, therefore, Kupang is a "state-dependent" town in the sense that the "state" is the main provider of jobs, the main source of construction projects, and the main stepping stone to political careers and regional leadership positions.

Between 2007 and 2010, I conducted approximately 12 months of fieldwork in city-level bureaucracy in Kupang. I wanted to find out how one could become a civil servant, get promoted within civil service, and obtain a construction project. Over the course of fieldwork, I came to realize that similar to, for instance, Russian blat (Ledeneva 2008) or Chinese guanxi (Yan 1996; Yang 1994), "getting things done" in Kupang partly hinges on reciprocal obligations and gift-giving practices within networks of personal relations. "Corruption" is not easily distinguished from other kinds of gift-giving practices because the circulation and exchange of money is always tied up with social relations and reciprocal obligations. This comes to the fore, for instance, in the many euphemisms surrounding the exchange of money (and favors). Money is never just money: it is a "smoother" (uang pelicin) or a way of expressing gratefulness (ucapan terima kasih diuangkan). "Collusion" and "nepotism" are, similarly, frowned on, whereas "helping out" (membantu) or "returning a favor" (balas jasa) to close ones (kedekatan, kenalan, keluarga) is perfectly understandable and acceptable. As Alena Ledeneva (2008) discusses regarding the moral ambiguity inherent in blat practices, what comes to be seen as "corruption” or amoral behavior from an outsider's perspective might be viewed more benignly by those engaged in it. "Private" exchange practices trickle over into public contexts, blur state-society boundaries, and cloud any straightforward definitions of what counts as "corruption" in Kupang. When does "helping out a close one" become "nepotism"? When does giving "thank you money" constitute an act of politeness and when does it constitute bribing?
Despite this on-the-ground ambiguity regarding what constitutes corruption (and exactly what counts as "public" and "private"), the bidding processes for construction projects in Kupang take place in a context in which World Bank definitions decide policy, and "corruption" is measurable in perception indexes and translatable into anticorruption programs. The failure of these programs to reach the desired effects might pose a puzzling paradox for policymakers and "integrity warriors" of Transparency International. But the works of, for instance, James Ferguson (1994), James Scott (1998), and Tania Murray Li (2007), which show all too clearly how schemes aimed at "improving the human condition" can backfire in unintended and unexpected ways, render these failures less surprising. Similarly, although the new anticorruption laws and regulations have not led to a significant decrease in "corrupt" practices, they have had some other effects. For instance, Rudi, an experienced contractor in his forties who owns four construction companies, listed all the investigation agencies related to the construction business. Instead of portraying these various audit bodies as being occupied with combating corruption, he sees them as intent on getting in on the action:

\footnotetext{
We have to be very careful because there are so many investigators that can be involved in investigating a project. There are internal investigation bodies on both province and regency level. There are also internal investigations straight from the center. For investigation agencies there are BPK; BPKP; Justice Department; police; army; KPK. KPK and the police are like lizards and crocodiles. The KPK is the smaller version, and the police the big, hungry version. It is not just businessmen that are involved. It is a world surrounded by Satan. What the investigations do is they add more people who want to share in the pie. [Conversation with author, November 3, 2009]
}

Rudi's statement supports the finding of scholars that the restructuring of the legal framework surrounding the tendering process and the establishment of anticorruption agencies have not led to a decrease of corrupt practices because it is still “a world surrounded by Satan." These extra parties, thus, do not necessarily alter illicit exchange practices, informal fees, and the importance of "good relations," which scholars have noticed in Indonesia's procurement sector since at least the 1980s (Sannen 1983; van Klinken and Aspinall 2011) and which I described above. However, framing this in terms of wider power relationships in which corruption is defined, these new parties do have the authority to start corruption investigations and expose "corruptors" and represent a frightening new kind of authority in bidding practices. So, one "effect" of anticorruption initiatives is the addition of new parties eager to "share in the pie" who hold a powerful threat of investigation over those unwilling to share.

Consequently, fear is another effect of anticorruption measures. Some civil servants under suspicion of corruption have become so fearful of possible investigation that they have even committed suicide (Purwanto and van Klinken 2010). This fear of anticorruption investigations was also tangible 
in Kupang. One contractor claimed that since President Yudhoyono promised to strike down hard on corruption there has been a steep rise in investigations: "Everybody who wants to win a tender can be reported these days. If there is an investigation, we can get arrested" (interview with author, September 29, 2008). In 2008, local contractor Cosmas Lay, who was well known and respected, was convicted and sent to prison for corruption in an unfinished infrastructural project in 2008 (Pos Kupang 2008). The contractors I asked all stated that they are far more afraid to end up in jail now than they were a few years ago.

The fear such examples evoke is reflected in an increased preoccupation with avoiding suspicion by keeping up an appearance of adherence to rules. For instance, the head of the Department of Public Works expressed his concern with avoidance of conspicuous behavior and the importance of sticking to tendering regulations. He expressed annoyance with various contractors' habit of visiting him at his house to sign up for a project or to submit a project proposal at the time of a tender. Contractors I interviewed, in contrast, tended to think such a personal approach of establishing or maintaining "good relations" with the head would increase their chances of winning the tender. The head himself, however, claims to tell these contractors off and to send them to the office to enlist at the proper place because "now we have to play by the official rules" (conversation with author, August 25, 2008).

During the 2008 tender, I noticed how heavily invested Public Works officials were in acting in accordance with the new rules. Throughout the tender, I witnessed many discussions at the Subdepartment of Water on how to interpret the plethora of sometimes contradictory and often unclear regulations on tendering. Desks were cluttered with explanatory law books of the kind commonly found in Indonesian bookstores, where they occupy entire sections, and many employees made serious attempts at understanding them. Leo, an ambitious Public Works employee in his thirties, told me he had recently purchased a copy of Presidential Decree 80/2003. He bought it to learn everything he could about the tendering process because, being young and still a fairly new employee, he found the process very hard to understand. Even the very experienced in the department, however, had difficulties understanding the entire process. Thinking many might need it, Leo brought the booklet to the office. Instead of finding a general disregard of rules (old or new), I found a great preoccupation with proper regulations and figuring out exactly how a tender should proceed. Because of this, I was repeatedly treated to extended elaborations on all steps involved in a tender by employees, often aided by self-drawn diagrams or references to information obtained from their law books.

During my time at Public Works, the tender was meticulously carried out in line with Presidential Decree 80/2003. First, after publicly announcing the upcoming tender via local newspapers, Public Works invited interested contractors to enlist in the bidding books and submit their associa- tion certificate, a personnel list, and a machinery list. After this, they organized a "clarification session" on all available projects to give prospective contractors more in-depth information regarding their respective projects. Those contractors still willing to compete were then given the opportunity to submit an official project proposal, consisting of a time schedule and proposed project value, and an "administrative package," containing the contractor's identification card, educational and occupational background information, and official company documentation. Special Public Works project committees consequently carefully reviewed submitted proposals via a "merit-point" system, which meant that the contractor who offered to complete the project fastest and at lowest cost gathered the most points. Committees judged the administrative package according to a "fail" (gugur) system. Those proposals that had administration packages that were incomplete or not in line with national guidelinesthat, thus, "failed" to meet official requirements - were dismissed.

However, this interest in figuring out the tendering regulations and making sure all procedures were followed properly, in particular in relation to submitted documentation, did not mean all regulations were actually followed. Rather, as I spent more time at Public Works, talked more to employees and contractors, and read the bidding books accompanying the projects, I found that what was followedpassionately — was the form of tendering rules and regulations.

\section{WHAT DOCUMENTS DO}

The anthropology of Indonesia has for a long time stressed the importance of form as an aesthetic and a performance of authority (Geertz 1981; Pemberton 1994; Siegel 1998). The importance of form in bureaucratic settings, however, is not unique to Indonesia. Don Handelman (1981) already characterized bureaucracy as a sociality organized by form. Michael Herzfeld (1992), furthermore, stresses how the use of a consistent form permits the perpetration of widely divergent bureaucratic practices. Uncovering the "symbolic roots of Western bureaucracy," he describes how the deployment of the rhetoric of kinship can achieve the seemingly opposing goals of providing an "easily understood model for the loyalty and collective responsibility that citizens must feel towards the state" as well as serving "more sinister aims" of bureaucratic inclusion and exclusion based on blood or race. The idea that the state rhetoric of kinship is merely symbolic obscures both the multiplicity of meanings symbols can engender and the role actors play in shaping symbolic meaning (Herzfeld 1992). As he so poignantly states, "rhetoric is never simply the pure art of classification. It is the practice of symbolic action - a process in which fixed form is often not only the mask, but even the enabling condition, for labile meaning" (Herzfeld 1992:69). To a certain extent, the argument I make here is similar, namely that the adherence to the form of the anticorruption rhetoric not only repeats and reconstitutes bureaucratic classifications of what counts as 
corruption but also enables novel practices that undermine this very discourse. However, I take a different approach to analyzing discrepancies and the interplay between "form" and "content." Although a focus on the multiplicity of meaning that symbols can engender offers a good analytic tool to look at why documents "do not do what they say they do," this symbolic or interpretive approach does, nevertheless, hold open the possibility that, if all surrounding conditions allow it, there can be an indexical relation between symbols and their meaning that would ultimately ground this relationship. In contrast, in my current exploration of documents and what they do, I do not want to focus on this possible grounding indexical relationship. Rather, I want to focus on the ever-present possibility that documents become unanchored from anticorruption discourse. To understand how this unanchoredness becomes possible, it is important to see how adherence to form emerges from the current assemblage of anticorruption, fear, and threats of investigation in Kupang. Adherence to form, then, reflects the importance of visibility and transparency necessary to avoid anticorruption investigations.

In her insightful study of intimacy and corruption in Thailand, Rosalind Morris (2004) describes how "transparency" has become the idiom with which a range of social and economic ills has come to be expressed. "Transparency," as a practice of making hidden processes visible, seems to indicate an "ethics of sincerity" (Morris 2004:226) and suggests a certain honesty - at least from an IMF or World Bank perspective. When political processes are therefore rendered visible and "transparent," surely they must be honest and sincere. But as the corruption scandal involving the Thai media tycoon Thaksin Shinawatra illustrates, this is not necessarily the case. Rather, this case shows that visibility, transparency, and ethics are not always so clearly equivalent and that visibility is often produced for its own sake. As Morris states:

\begin{abstract}
The law works in the realm of appearances, of what can be seen and what can be hidden. What matters now in Thailand is that everything be visible, and more: that the processes of making visible, of moving things from the domain of the secret into that of the public, themselves be revealed, unfurled in the brilliant light of the media's perpetual day. [Morris 2004:233-234]
\end{abstract}

In line with this, I suggest that in Kupang, under the pressure of possible investigations, visibility has similarly become important as a way of conveying an adherence to rules. The step-by-step process of conducting a tender as described in the previous section echoes the same need for neoliberal "transparency" as Morris shows in Thailand. If the tender is conducted in a transparent manner, then surely it must be honest and free from "corruption." As in Thailand, the law in Kupang works in the realm of appearances, of what can be seen, read, and proved. If what can be seen, read, and proved - and thus rendered "visible" - is in accordance with the letter of the law, there is no "corruption" to be investigated. This, I suggest, helps us understand why visibility, or the adherence to form, which the Department Head displays when insisting contractors enlist at the office instead of his house and the Public Works officials show when arguing over the correct interpretation of confusing and contradictory rules, is so important. This becomes particularly clear in the most visible and tangible objects that circulate in a tender, namely documents.

The looming threat of investigation makes it important not only for Public Works officials to convincingly adhere to official rules and regulations during a tender but also for contractors to present an immaculate package. Because they know very well that failure to adhere to the proper form of the administrative package can lead to disqualification in the bidding process, contractors pay particular attention to the correctness of their proposal and administrative package. Because of this, some Public Works employees rent out their expertise in tendering regulations to contractors to help them draft correct administrative packages and bidding proposals. While interviewing Leo, the Public Works employee who bought the Presidential Decree 80/2003 booklet, one night over dinner, our interview got repeatedly interrupted by incoming phone calls. I could hear Leo give the person on the line directions to our restaurant. After a while, a man showed up and Leo took him to a corner table of the restaurant. They chatted for a few minutes and then Leo saw the man out and returned to our table. With a bright smile on his face, Leo exclaimed, "this is KKN!" It turned out the man was a contractor who had asked for Leo's help in making sure his documentation was in order. Leo accepted this request and told me he helped a few other contractors as well for the lucrative fee of IDR500,000 (US\$55, about half or a third of a starting civil servant's monthly salary) per contractor.

The heightened preoccupation with the appearance of adherence to regulations that we saw in the department head's urging of contractors to enlist at the proper location thus becomes particularly visible in the various documents involved in the tendering process. After all, documents constitute materialized proof of wrongdoings, which can be used in investigations. These documents that were drafted with Leo's paid help show no visible digression from the letter of the law. Yet, the fact that Leo accepts payments from contractors to draft the documents he and his coworkers will later evaluate in the tender contradicts the stipulations of the legal reforms laid down in Presidential Decree 80/2003. The efforts Leo undertook to get acquainted with all aspects of the decree actually enabled him to engage in new ways of making money, which, in fact, countered the spirit of transparency, fair competition, and the anticorruption stance underlying the decree. As with Morris's Thai example, the visibility displayed in these tender documents therefore does not necessarily convey the kind of "transparency" with its connotations of "sincerity" and "honesty" that is favored by the World Bank and IMF. Such documents adhere to the law's letter, but they also do something else - offer Leo a way to make some extra money on the side. They visibly carry out compliance with the 
anticorruption discourse yet enable a new form of corruption in their production.

Besides offering Public Works officials a new way to make money, documents also "do" other things that counter and subvert the anticorruption discourse to which they so visibly adhere. Ironically, adherence to the proper form of documents has also become a means to legitimize an informally won bid. Michael, a contractor with years of experience in the construction business, explained that even when you know your proposal is more competitive than that of a rival contractor favored to win, the Public Works' project committee can always find problems in your submitted administration: a stamp that was forgotten or a signature that was omitted. Failure in adherence to the proper form of documents - proper punctuation and required signatures and stamps - instead of the competitiveness of the proposed bid can be used as a legitimate reason to disqualify contractors, something the contractor in the opening of this article already lamented. Rudi, another contractor, refers to such minor administrative problems as "lice" and reveals a flipside to Michael's experience: when "lice" are found in his documents, Public Works employees will notify him and give him the chance to improve his proposal, so all documents are "lice free" in case of an investigation. In Michael's case, his proposal ought to have formally won based on the "merit" and "fail" point system of evaluating bidding documents described previously. However, because another contractor had won the project informally, Public Works employees seek out trivial mistakes in his documents - or even actively make certain necessary forms disappear-so that Michael's documents show a digression from the proper format of tender documents as laid out in the new tendering rules. Rudi, conversely, shows how his documents are made to display adherence to the proper format so that they do not convey the informal bidding process through which he won.

Both examples illustrate how adherence to form has become a means through which to formalize an "informal" admission or rejection of competitors in a tender. Indonesia's anticorruption efforts have thus resulted in the importance of adherence to form of documents, which has increased documents' "visibility" (as displaying all necessary tender requirements) but not necessarily their "transparency" (in the sense of preventing "corrupt practices"). What documents therefore "do" by adhering to the proper form is provide informal bidding processes with a visible and tangible layer of legitimization. Yet, by adhering to the form of anticorruption discourse, they nevertheless still perform a taxonomic act of bureaucratic logic (Handelman 1990). As other performances of anticorruption rhetoric do-for example, TV reports, newspaper articles, department heads' speeches, stickers, and pamphlets - these documents, by adhering to the proper form, emphasize over and again what counts as "corruption" and in so doing repeat the bureaucratic classification of the recently revised category of "corruption." The reality that such repeated performances produce is ambiguous and contradictory. On the one hand, documents reproduce and maintain the dominant anticorruption discourse codified in the letter of the law; on the other hand, they mask and enable practices that contradict and subvert this discourse.

Similar effects of adherence to form have been observed in other bureaucratic contexts. Alexei Yurchak (2006), for instance, pays attention to the interrelatedness of the "performative" and "constative" dimensions of speech and public discourse in his ethnography on late socialism to help explain the collapse of the Soviet Union. Yurchak claims that during late Soviet socialism, a "performative shift" took place: the performative dimension of authoritative speech and discourse became far more important than its constative meaning. For example, he describes how participants of Komsomol meetings in the 1970s and 1980s would spend their time reading books yet would not fail to raise their hand automatically whenever votes had to be taken - even when unsure and uncaring about the topic of the vote. In other words, they adhered to the general form of an authoritative discourse ritualized in a meeting without engaging in its meaning (Yurchak 2006). Participation in the reproduction of form became increasingly important in all sorts of ritualized acts, such as meetings, speechwriting, and propaganda painting. Of key importance is that although the constative meaning of the discourse, repeated and reproduced in performative acts, lost importance, this did not render such acts meaningless. Rather, these performative acts enabled various new and unexpected meanings unrelated to the constative meaning of authoritative discourse. For instance, the performance of form enabled Komsomol members or office workers to maintain the kinds of professional and personal relations necessary to engage in the kinds of activities that were important and meaningful to them and to live what Yurchak calls "a normal life" (2006:118).

More specifically, studies on documents also show an interest in the importance of form, iterability, and the possibility of rupture. Annelise Riles (2001) pays meticulous attention to the aesthetic qualities of the 1992 Pacific Platform for Action document. Drafting this document - in particular, filling the not-yet-decided-on content of the "brackets"involved mainly the production of "properly patterned language" (Riles 2001:80). This document, therefore, represents a carefully selected and negotiated reiteration of countless preceding documents in which aesthetic conventions regarding layering and patterning mattered more than the "meaning" of the words used. In Riles's case, repetition facilitates an emphasis of form over meaning. Marilyn Strathern addresses university mission statements in the United Kingdom as "utterances of a specific kind, namely a turnof-the-century language of good governance" (2006:194). Similar to Riles, Strathern shows how the replication of this kind of utterance makes content subordinate to form. Additionally, however, she also demonstrates that the textual form of those statements actually opposes the task of education. Additionally, Veena Das (2004), when asking how the state can claim legitimacy in the face of obvious forgery and 
corruption, claims that iterability allows documents to be reproduced, forged, and used infelicitously out of context. This iterability, however, does not signal vulnerability but, rather, in a sense, a multiplying of state power — even when carried out infelicitously without the signature of the state. For Das, iterability of state authority in documents - even in the case of forgery - thus adds to the legitimacy of the state.

With these examples, I hope to show that such documents - like those in the tender process - do not always do what they say they do and, in fact, often do other things, whether emphasizing form over content, contradicting intentions of a discourse that documents supposedly represent, or legitimizing illegitimate claims. The effects of the project proposals and administrative packages described above are therefore not shocking bureaucratic anomalies or deviations from the anticorruption discourse but exemplify an ever-present possibility of unanchoredness from context. The iterability of the anticorruption discourse - reiterated numerous times in the layout of the project proposals and administrative packages; in the booklets on Presidential Decree 80/2003, which circulated in the Public Works department; in the decree itself; in the "vision and mission statements" of the newly founded audit bodies; and in statements on "good governance" as proclaimed by NGOs such as Transparency International - makes such an unanchoredness possible. The concern with documents' form in a tender therefore exceeds a certain "aesthetics of bureaucratic practices": a concern with "pattern"-proper punctuation, official procedures, correct spelling, and so forth-over substance (Riles 2001:16). Adherence to form ambiguously ensures the documents' compliance with the anticorruption discourse as well as a possible breach from it.

Let us now turn to the bidding books to see how this adherence to form of the anticorruption discourse enables corrupt practices while still serving as "proof" of sticking to the rules in the event of an investigation.

\section{BIDDING BOOKS: HIDDEN INCONSISTENCIES}

The fall 2008 tender livened up everyday routines at the Department of Public Works. Officials, who, as they admitted to me, occasionally got bored at the office due to a lack of tasks to perform, were busily engaged in tender preparations. Bidding books were drafted in which would be noted how many contractors signed up for a given project, how many consequently handed in a proposal, and, finally, who won. Clarification sessions were organized during which interested contractors could find out more about the various projects offered. Most importantly, the tender provided officials and contractors, many of whom see each other at every tender and at various formal occasions in Kupang's fairly limited social circles, with an opportunity to reconnect and catch up. After the public announcement of the tender in a local newspaper on August 22, 2008, a steady stream of contractors and representatives from local construction companies stopped by to enlist, join clarification sessions, and submit proposals. Many contractors lingered to inquire about family members or to sit down, smoke cigarettes together, and chat. These amiable interactions continued into the clarification sessions I joined, in which contractors and officials engaged in a constant good-natured bantering back and forth. Yet, it should not be forgotten that amid this pleasant sociability a competition for profitable construction projects was taking place that left its - albeit hardly perceptible - traces in the bidding books.

On the surface, the bidding books that the Department of Public Works made available for the 35 projects it advertised certainly suggested a thriving market-oriented competition between a number of construction companies in line with Presidential Decree 80/2003. Initially intending to compile an up-to-date list of construction companies in Kupang, I set out to check all bidding books and write down the names of the companies and their owners. Assembling such a list was a daunting task that took days. Determined to get an idea of the number of construction companies, I nevertheless jotted down the names of all the companies that had enlisted for each project. The long and tedious task of manually copying the bidding books (227 companies were listed for the 35 projects), however, also revealed certain inconsistencies that suggested the bidding books do more than perform an adherence to the new tender rules and regulations.

Unsurprisingly, I found that some companies had enlisted for more than one project. However, one thing that did stand out in several bidding books was that whole clusters of entries were written down in the same handwriting, even though the companies enlisted had different names, different owners, and a unique stamp. Furthermore, when comparing the names of the companies that had enlisted in the bidding book with those that had handed in an actual project proposal during a later stage in the bidding process, it became clear that some companies had enlisted many times but had never handed in a proposal. Company Amin, for instance, had enlisted seven times without handing in a single proposal. Hiasan Cahaya had enlisted 19 times yet also never handed in a proposal. In contrast, the company Pengharapan Perkembangan had enlisted for only one project, handed in one proposal, and consequently won the tender.

These inconsistencies are not proof of foul play per se, and this is the strength of the bidding books as a materialized performance of adherence to rules. Perhaps some helpful employee wrote down the names of several companies waiting in line to enlist in the bidding books, which could explain the similarity in handwriting (but why did the signatures put in by a representative of the company still look so similar?). Perhaps Hiasan Cahaya lost its courage after the clarification phase of all 19 projects it signed up for and decided to withdraw from all of them. Perhaps Pengharapan Perkembangan decided to place all bets on one horse and won because of the effort put into that single proposal. I discussed these inconsistencies with Christian, a lower-level employee at Public Works: 
Sylvia Tidey: So there are some companies that enlisted in the bidding book, yet never handed in a proposal?

Christian: Oh yeah. These probably enlist to make it look as if there is a competition, a strong-enough competition. So if we just look at the list, it will look like, "wow, so open! Everybody can enter." But in fact, it will just go to one person. One person enlists and invites some friends to enlist as well. But this is just in order to make it look crowded.

ST: So there are some that only enlist to make the list look good, they never want to hand in a proposal?

C: They are just used to liven [the list] up (meramaikan saja). That is not good.

ST: Then there are companies that were enlisted in the same handwriting. Why is that?

C: The same reason. To fill the list and make it seem as if there is competition. To make it look fair. While actually, the competition is between only three contractors. So these just invite their friends to enlist. [Interview with author, October 16, 2008]

Christian claims that some of the discrepancies I foundentries in the same handwriting, companies enlisting yet never handing in a project proposal — are strategies to ensure the appearance of a "strong-enough competition" and "to make it look fair." Comments such as these suggest that behind the fair competition performed by the bidding books, another kind of competition takes place. A few examples from interviews with contractors and Public Works officials provide some insights into the mechanisms of this informal competition made possible by the formal appearance of the bidding books.

According to some contractors, the "fair competition" that can be read from the bidding books actually masks a contest that was won far before the tender opened. For the funding of projects, the Public Works department is dependent on revenue allocated by the central government to fund their projects. For some contractors, this is where the competition for a project begins, as Rudi explains:

Rudi: With regards to lobbying, we can go to the center. This is lobbying for the budget, meaning the budget for the upcoming year at national parliament.

Sylvia Tidey: What are you lobbying for then?

R: That is lobbying for state budget.

ST: That is lobbying in the center so the funds for the region are bigger? Have you ever done that?

R: Yeah, the lobbying in the center is carried out so the allocation of funds is bigger. For instance, once I have gotten a project worth seventeen billion [approximately $\$ 2,000,000$ ] that was going to be sent down [from center to region] like this. We had to prepare five percent of that amount, so a friend and I had to pay about 750 million [almost $\$ 8,500]$.

ST: In which way did you give an amount that big? Via a bank account?

R: We brought cash, not a check, so it could not be verified. So while they were still here [in Kupang] that money was given directly, because if it would have been given in Jakarta we could have been arrested. And as long as they were here, we would pay for their enjoyable stay, for their hotel and so forth. [Interview with author, November 9, 2009]

Here Rudi talks about one way of securing projects, namely by "lobbying" for funding for construction projects in the regions with members of the national parliament (the "they" in his story). Through this kind of lobbying, he has once managed to get a large project worth IDR 17 billion allocated to the region. By offering around five percent of the total project value to these parliament members, he secured his company the right to execute the project. The bidding book for this project, therefore, hides the lobbying process that resulted in its existence and also gave a false impression of competition because other contractors who had signed up for this project stood no chance of winning. Furthermore, Rudi shows some concerns about getting caught, which is why he prefers to leave no trail of this illegal transaction by paying in cash and ensuring the transaction took place in the familiar surroundings of Kupang. In other words, in the realm of visibility there is no visible, tangible, provable trace of corruption. All that is rendered visible is his submitted documentation - the project proposal and his administrative package, which no doubt display adherence to form and therefore suggest "transparency." The bidding book in this case similarly portrays an open and fair competition among several contractors without traces of manipulation. As such, it legitimizes Rudi's informal lobbying with members of the national parliament.

Rudi's example of local contractors who "lobby" in the capital for an allocation of project funds to be sent down from center to region contrasts nicely with Joshua Barker's (2005) description of the strategies that the state-owned electronics enterprise LEN (Lembaga Elektronika Nasional) employed to sell its earth stations, devices that pick up satellites' broadcast, after the installation of Indonesia's own satellite. In this case, LEN "lobbied" with regional government officials and military by emphasizing how acceptance of these earth stations would offer them the opportunity to showcase their " 'national development' on the local level" (Barker 2005:718). Lobbying in the "region" by "agents" from the center was carried out using a rhetoric of national consciousness. In Kupang, however, the lobbying in the center initiated by local "agents" reflects an interest in keeping things local. Public Works officials and contractors alike whom I interviewed mostly expressed a preference for keeping available government projects "in house" by having them be executed by "local" contractors as opposed to "big" contractors from, for instance, Jakarta or Surabaya. The reason for this, according to a Public Works official I interviewed, is that "their manner of pergaulan (fraternization) is unknown to us, so we don't know how to suap-menyuap (engage in bribery) with them. At least the people here know how it works" (interview with author, October 16, 2008).

Most "lobbying," therefore, takes place in Kupang. "Lobbying" is not just done in Jakarta, and not all projects 
are decided on in advance. When discussing how to succeed during a tender, Niko, a small contractor, told me that despite all the regulations, contractors still have to "lobby" to get contracts. Contractor Alfred explained the importance of having acquaintances or "good relations" in lobbying for projects. After his enlisting has been accepted by the tender committee, he approaches either all committee members or just the head of the committee. He knows that money given to the head of the committee will trickle down to all committee members and thus make them all judge his proposal favorably, but he prefers to spend some time - and money - on all separate members. Already having relations with one or more committee members, however, is best. Established relations with committee members facilitates the lobbying process: the committee members know you, might feel obliged to help you out, and can count on the relationship they have with you as an extra stimulus for you to get the job done in time and properly. Leo, the ambitious young Public Works employee, recognizes these ways of lobbying and confirms their-sometimes - success. He distinguishes lobbying "from above" from lobbying "from below." Leo has seen influential and wealthy contractors lobbying from above by contacting the head of the Department of Public Works - the one who supposedly urged contractors to stay away from his house because "now we have to play by the rules" - after which the head makes it known to lower-level employees who is supposed to win. Contractors lobbying from below sometimes give money directly to the committee head but, as Alfred stated, most prefer giving money to all members of the tender committee "so [that] the relations are good" (conversation with author, October 10, 2008).

Another important aspect of good lobbying for projects is having proper financial backing. Officially, a contractor's bid is judged on the amount of time and money needed to execute the project: the contractor that offers to finish the project fastest and cheapest wins. This contractor then gets (an advance of) the total project value from the Department of Public Works to fund the project. Unofficially, however, as explained to me by various contractors, bids are judged on the percentage of the total project value that the contractor promises to return to the tender committee as an informal fee, euphemistically labeled "commitment." As one contractor explained:

\footnotetext{
Ok, it's like this. We want to get a project. For that we have to show a certain commitment. This can be 5 percent, 7.5 percent, 10 percent, 12.5 percent or 15 percent ... If our commitment is hesitant, another contractor with a bigger commitment will get it. This is not yet a guarantee that we'll get it. They can give it to someone else. They can find mistakes in our administration. [Interview with author, October 2, 2008]
}

Interestingly, this contractor notes how form- -"mistakes in our administration" - can be used to delegitimize a contractor's bid when another contractor has offered a larger "commitment," suggesting again that visible adherence to the form of the anticorruption discourse matters. Even after having been allocated a project, the money flow to Public Works officials does not stop:

\begin{abstract}
There is also "returning-a-favor money" (uang balas jasa), this is given throughout the project, not at the beginning. It can happen that he [committee member] wants to go somewhere. He then asks us for a ticket. That is "answering back." . . . And if we don't give this money, sometime in the future they will discredit us. So they will refuse us other projects, so they refuse us in a very polite way. [Interview with author, October 2, 2008]
\end{abstract}

Money does not just flow from contractors to officials (or to the new auditors); it also circulates among contractors. As I flipped through the bidding books for all 35 projects during the tender and saw list after list with names of companies, names of owners, and stamps, one final discrepancy caught my attention. As we recall, 227 companies enlisted for a mere 35 projects in a town where, as I mentioned before, most contractors are dependent on government projects. Because adherence to form demands all documents in a tender to be fully in line with the new rules and regulations, only contractors who could provide the proper administrative package were allowed entrance into a tender. How could so many construction companies survive in Kupang? Were these "real" companies? If so, why would so many only enlist yet never hand in an actual bid? Why bother enlisting when lacking the financial backing or lobbying skills to engage in informal competition?

Most, if not all, of the companies enlisted in the bidding books are "real" in the sense that they are a member of one of the acknowledged construction associations and therefore have all proper administrative backing to be allowed entrance into a tendering process. Yet, as research on the construction sector in other parts of Indonesia has found, many associations entering a tender do not have an office, let alone machinery or employees to execute any type of construction project. In that sense, these "flag" companies are thus fictive competitors (van Klinken and Aspinall 2011). Such fictive companies enlist for various reasons. One is as a favor to an actual competitor who does have the intention of joining the informal bidding process, which explains why some of the entries in the bidding book are written down in the same handwriting. At the time of signing up, the actual competitor also enlists the names of a few friends (with fictive companies) "to make the list look good." As a thank you for lending their names and stamps, a small fee or even percentage of the project value, often referred to as "withdrawal money," may be given. Little fees for backing out of the competition are also a reason many fictive companies sign up. A retired entrepreneur who plays tennis with a few young owners of such fictive construction companies explained to me that many companies do not have the ambition to ever hand in a project proposal. They are merely "fee seekers" in it for the "withdrawal money" that actual competitors offer them. In the meantime, these informal fee seekers and receivers of thank-you money do add to the adherence to the form of the anticorruption discourse 
displayed in the bidding books by making the competition look real and in line with official regulations.

It is tempting to view the bidding competition in $\mathrm{Ku}$ pang simply as a means of various involved parties to seek rents, to - as contractor Rudi stated previously — "share in the pie." However, couched as it is in euphemisms of building "good relations," "lobbying," "commitment," "returning a favor," "answering back," and "withdrawal fees," the circulation of money in the tendering process cannot merely be understood in terms of economic gain. Rather, money flows intimately follow social ties and the reciprocal obligations implied therein. What counts as "corruption" under the letter of the law was framed as proper behavior during the Kupang tender. To illustrate how money is tied up with social relations, John, the head of Kupang's chamber of commerce, posed a personal dilemma:

\begin{abstract}
When asked at a family party to give a project to a family member, one cannot really refuse. Projects in Kupang are small, and there aren't many. When lucky, a contractor might get one project a year. The profits contractors get from a project are not very big, so what would happen if the relative does not get a new project? How will he live? How will he eat? [Interview with author, October 27, 2008]
\end{abstract}

The obligation felt toward the relative in this example at times motivates John to give projects to family members when solicited. As officials told me during informal chats, the commitment contractors give "from above" trickles down to the lower echelons of the department not just to make sure no employee will talk but also because it is the proper thing to do. Paying withdrawal fees to friends and fictive competitors who enlisted to fluff up the bidding books is a sign of politeness so, as one contractor explained, "we can all get something" (conversation with author, November 3, 2009). Contractor Niko, mentioned previously, gave me another example of intercontractor loyalty after he won three projects during one tender. He claimed to feel bad about having obtained so many projects and therefore decided to subcontract two of those to other contractors so they could profit as well. Although he still expected to receive a percentage of the project value as a return for his generosity, he framed his actions to me as a matter of good manners, of "returning a favor." Without wanting to overly romanticize internal loyalty among the various participants in the 2008 tender, I do want to show how these informal bidding processes are embedded in existing local networks of reciprocal obligations in which the ways of pergaulan and suap-menyuap are clear. "Fairness" in the tendering process does not connote a neoliberal, market-oriented competition, as recent anticorruption efforts tried to produce, but rather sharing the pie in such a way that "we all get something." The exchange of money and favors in Kupang's construction sector therefore challenges clear-cut conceptions of "corruption" and blurs boundaries between state and society, legal and illegal, and right and wrong.

However, in this ethnographic exploration of the effects of recent structural anticorruption efforts in an eastern Indonesian construction sector, I have done more than chal- lenge unambiguous definitions of what constitutes "corruption." I also showed how from the current configuration of anticorruption efforts, state programs, audit bodies, and fear of investigation in Indonesia visibility, tangibility, and provability have emerged as important tropes to deflect investigations into possible "corrupt activities." Similar to corruption scandals in present-day Thai politics as described by Morris, however, this "visibility" does not indicate the "transparency" for which anticorruption schemes aim. Instead, the adherence to the form of the anticorruption discourse that the documents I described here display reinforces this discourse through the documents' constant reiteration of proper form in the same sense that Das's forged documents add to the legitimacy of the state. However, like Yurchak's description of what he calls a "performative shift" during late socialism, the adherence to the proper form also enables a continuation of existing informal gift-giving practices as well as makes possible new forms of "corruption." These informal bidding processes thus do not take place outside of anticorruption ideology or state power; instead, they are inextricably linked to them. ${ }^{6}$

\section{CONCLUSION}

The anticorruption discourse, traceable back to the World Bank's rigid definition and anticorruption initiatives, has become ubiquitous in Indonesia. There is broad media coverage and condemnation of cases of suspected corruption on national and local TV, newspapers, and blogs. Local bureaucracy is similarly immersed with anticorruption rhetoric: aspiring civil servants take special classes on corruption during their civil-service preparatory course (Diklat); department heads condemn the evils of corruption, collusion, and nepotism in their speeches on Monday morning roll calls; the problem of how to eradicate corruption is a fruitful source for workshops and seminars; gossip about the suspected corrupt practices of local big shots fuels endless conversation in the office; and stickers and posters urging civil servants not to engage in corrupt practices are found throughout offices. As Gupta notes with regard to the state in North India, corruption "has become implicated in the minute texture of everyday life" (1995:375). Seemingly without exception, civil servants in Kupang consider corruption to be something "bad," morally despicable, and - as I often overheard - a hindrance to development. Yet, as I discussed, even though the revised legal framework states what counts as "legal" and "illegal" - that is, violations of the law's letter - ascertaining what is "right" versus what is "wrong" in Kupang is less clear. Adding to the mismatch between legal and illegal and right and wrong is the fact that the auditors who are supposed to represent the law and investigate violations of the law's letter engage in the kinds of practices they are supposed to expose.

In this article I have looked at how anticorruption programs in Indonesia affected the 2008 fall tender at the Department of Public Works in a provincial capital in eastern Indonesia. I have shown how initiatives aimed at curbing corruption in the construction sector got refracted at the local 
level, became unanchored from their original intention, and produced some effects that undermined the anticorruption initiative. What these programs did, particularly in light of some high-profile national as well as local corruption investigations, was produce a fear of possible investigations among contractors and Public Works officials. To avoid suspicion of corrupt behavior, contractors and officials displayed a preoccupation with adherence to the form of the anticorruption discourse, as exemplified by the department head's urging of contractors to enlist at the proper place, officials' obsession with figuring out the tender rules and conducting the steps of the tender in line with Presidential Decree 80/2003, and contractors' paying of officials to draft proper documents. This adherence to form became, I argue, particularly visible in office documents, those bureaucratic artifacts in which "corruption" can be read and proved most easily. However, although the various documents that circulated during the tender visibly adhered to the anticorruption discourse, they, nevertheless, also enabled a continuation of informal (and illegal) practices and provided new opportunities for corruption.

In the midst of a rise in anthropological attention to "corruption" and a focusing of the anthropological gaze on documents, I shed light on how documents are entangled with and even make possible certain kinds of "corrupt practices." Ethnographic attention to documents and corruption is increasingly necessary in light of the influential anticorruption programs and initiatives based on hegemonic and unambiguous definitions of "corruption" as propagated by the "moral crusaders" of Transparency International and similar organizations that increasingly impact localities such as Kupang in unexpected and contradictory ways. Similar to Morris's (2004) discussion of "transparency" and "visibility" in Thai politics, what emerges from the current conjuncture of anticorruption discourse, threats, fear, and a neoliberal need for transparency in Kupang is the importance of visibility, tangibility, and provability. If what is visible, tangible, and provable in Kupang shows adherence to the anticorruption discourse, then surely there is no corruption. It is this questionable conclusion of the anticorruption discourse that makes ethnographic attention to material bureaucratic artifacts such as documents so pertinent.

Ultimately, I have argued that documents provide a significant ethnographic point of departure from which to study the "contradictory, messy, and refractory effects" of government interventions ( $\mathrm{Li}$ 2005:391). This is especially the case when such documents perform the double effect of offering proof of adherence to rules in the case of an anticorruption investigation while enabling new forms of corruption, and thus ambiguously both strengthen the anticorruption discourse and subvert it.

Sylvia Tidey Department of Anthropology, University of Amsterdam, Amsterdam 1012DK, The Netherlands s.tidey@uva.nl

\section{NOTES}

Acknowledgments. This research is part of the "In Search of Middle Indonesia" research program that was initiated by the Royal Netherlands Institute of Southeast Asian and Caribbean Studies (KITLV). It has been generously funded by the Royal Netherlands Academy of Arts and Science (KNAW). I would like to express my appreciation to Henk Schulte Nordholt, Gerry van Klinken, Jarrett Zigon, and Annemarie Samuels for reading a previous draft of this article and for their helpful suggestions. I am also very grateful for the stimulating comments made by the anonymous reviewers of American Anthropologist and for the kind and constructive guidance offered by Tom Boellstorff and Michael Chibnik. In order to protect the identities of the people who have so generously shared with me their experiences and thoughts on fairly sensitive topics, I use pseudonyms throughout this article. I also changed the names of the construction companies I mention.

1. The legal backing for these changes was provided among others by the ratification of Act 31/1999 on the eradication of corruption by the first post-Suharto president Habibie (later amended in Law $31 / 1999$ by his successor Wahid); the issuing of Presidential Regulation 19/2000 on a joint team to combat corruption and Presidential Regulation 71/2000 on public participation to eradicate corruption by Wahid; the ratification by former president Megawati of Law 30/2002 that enabled the formation of the anticorruption commission KPK; and current president Susilo Bambang Yudhoyono's consequent issuing of Presidential Instruction 5/2004 on accelerating the eradication of corruption.

2. For an excellent and more elaborate discussion of corruption in government-funded construction sectors, see van Klinken and Aspinall (2011).

3. Whereas in the capital Jakarta and tourist hotspots such as Bali this percentage can be expected to be lower, the vast majority of contractors in the regencies and provinces outside Java and Bali rely on government funding.

4. Additionally, it prescribes stricter stipulations regarding the tendering process. For instance, all projects offered via tendering should be announced publicly, and competing contractors no longer have to be members of the national Chamber of Commerce but only to be licensed by one of the existing business associations.

5. KKN is the popular Indonesian acronym for the "unholy trinity" of corruption, collusion, and nepotism (Korupsi, Kolusi, dan Nepotisme).

6. The question remains of whether and how these informal giftgiving practices might affect anticorruption ideology and state power. Analyses of comparable practices offer possible answers. Yang (1994) and Ledenova (2008) also stress the intertwinedness of informal gift-giving practices with state power in their analyses of guanxi and blat under the influence of state socialism. Both scholars recognize how guanxi and blat, on the one hand, each helped to preserve the ideological tenets of state socialism, while, on the other hand, they undermined the ideology of a socialist state. To a certain extent, this paradox does not seem to threaten the state. In her discussion of blat and guanxi, Ledenova, for instance, notes: "By both sustaining and subverting state ideology, 
informal practices enabled socialist regimes based on mutually parasitic attitudes between the state and the people to survive" (Ledeneva 2008:125). Yang, in contrast, views guanxi practices as holding a greater possible subversive effect on state power:

\begin{abstract}
The gift economy not only challenges official power, it also subverts the dominant mode of economy. In other words, prefigured in the distributive economy are the seeds and possibilities of challenges to its power. The gift economy ... 'poaches' on the territory of another mode of exchange, seeking the right occasions to strike and divert resources to its own method of circulation. In the process, it alters and weakens in a piecemeal fashion the structural principles and smooth operations of state power. [Yang 1994:189]
\end{abstract}

So perhaps the antagonism between sustaining and reiterating state-propagated anticorruption efforts, which I describe here, and the possibilities for subversion because of digressions from the discourse (such as gift-giving practices) holds a possibility for challenging state power in Indonesia.

\section{REFERENCES CITED}

Aspinall, Edward, and Gerry van Klinken

2011 The State and Illegality in Indonesia. In The State and Illegality in Indonesia. Edward Aspinall and Gerry van Klinken, eds. Pp. 1-28. Leiden: Koninklijk Instituut voor Taal-, Land-, en Volkenkunde [Royal Netherlands Institute of Southeast Asian and Caribbean Studies].

Barker, Joshua

2005 Engineers and Political Dreams: Indonesia in the Satellite Age. Current Anthropology 46(5):703-727.

Blundo, Giorgio, Jean-Pierre Olivier de Sardan, N. Bako Arifari, and M. Tidjani Alou

2006 Everyday Corruption and the State: Citizens and Public Officials in Africa. London: Zed Books.

Das, Veena

2004 The Signature of the State. In Anthropology in the Margins of the State. Veena Das and Deborah Poole, eds. Pp. 225-252.

Santa Fe, NM: School of American Research Press.

Davis, Jennifer

2004 Corruption in Public Service Delivery: Experiences from South Asia's Water and Sanitation Sector. World Development 32(1):53-71.

Ding, Xueliang

2001 The Quasi Criminalization of a Business Sector in China; Deconstructing the Construction-Sector Syndrome. Crime, Law and Social Change 35:177-201.

Ferguson, James

1994 The Anti-Politics Machine: "Development," Depoliticization, and Bureaucratic Power in Lesotho. Minneapolis: University of Minnesota Press.

Geertz, Clifford

1981 Negara: The Theater State in 19th Century Bali. Princeton, NJ: Princeton University Press.

Gupta, Akhil

1995 Blurred Boundaries: The Discourse of Corruption, the Culture of Politics, and the Imagined State. American Ethnologist 22(2):375-402.
Haller, Dieter, and Cris Shore, eds.

2005 Corruption: Anthropological Perspectives. Ann Arbor, MI: Pluto Press.

Handelman, Don

1981 The Idea of Bureaucratic Organization. Social Analysis 9:523.

1990 Models and Mirrors: Towards an Anthropology of Public Events. Cambridge,UK: Cambridge University Press.

Harrison, Elizabeth

2006 Unpacking the Anti-Corruption Agenda: Dilemmas for Anthropologists. Oxford Development Studies 34(1):15-29.

Herzfeld, Michael

1992 The Social Production of Indifference: Exploring the Symbolic Roots of Western Bureaucracy. Chicago: University of Chicago Press.

Holston, James

1991 The Misrule of Law: Land and Usurpation in Brazil. Comparative Studies in Society and History 33:695-725.

Hull, Matthew S.

2003 The File: Agency, Authority, and Autography in an Islamabad Bureaucracy. Language \& Communication 23:287-314.

2008 Ruled by Records: The Expropriation of Land and the Misappropriation of Lists in Islamabad. American Ethnologist 35(4):501-518.

2012 Documents and Bureaucracy. Annual Review of Anthropology 41:251-267.

Kurniasih, Elysabeth Dwi, and Prapto Yuwono

2004 The Illegal Retribution Faced by the Construction Business: A Case Study in Salatiga. KRITIS Jurnal Studi Pembangunan Interdisiplin 16(1):1-23.

Latour, Bruno

1988 Drawing Things Together. In Representation in Scientific Practice. Michael Lynch and Steve Woolgar, eds. Pp. 19-68. Cambridge, MA: MIT Press.

Ledeneva, Alena

2008 Blat and Guanxi: Informal Practices in Russia and China. Comparative Studies in Society and History 50(1):118-144.

Li, Tania Murray

2005 Beyond "the State" and Failed Schemes. American Anthropologist 107(3):383-394.

2007 The Will to Improve: Governmentality, Development, and the Practice of Politics. Durham, NC: Duke University Press.

MacLennan, Carol

2005 Corruption in Corporate America: Enron-Before and After. In Corruption: Anthropological Perspectives. Dieter Haller and Cris Shore, eds. Pp. 156-170. Ann Arbor, MI: Pluto Press.

Morris, Rosalind

2004 Intimacy and Corruption in Thailand's Age of Transparency. In Off Stage/On Display: Intimacy and Ethnography in the Age of Public Culture. Andrew Shyrock, ed. Pp. 225-243. Stanford, CA: Stanford University Press.

Pardo, Italo, ed

2000 Morals of Legitimacy: Between Agency and the System. Oxford: Berghahn Books.

2004 Between Morality and the Law: Corruption, Anthropology, and Comparative Society. Burlington, VT: Ashgate. 
Pemberton, John

1994 On the Subject of "Java." Ithaca, NY: Cornell University Press.

Poole, Deborah

2004 Between Threat and Guarantee: Justice and Community in the Margins of the State. In Anthropology at the Margins of the State. Veena Das and Deborah Poole, eds. Pp. 35-66. Santa Fe, NM: School of American Research Press.

Pos Kupang

2008 Cosmas Lay ditahan [Cosmas Lay arrested]. August 1: 1.

Purwanto, Erwan, and Gerry van Klinken

2010 Eluding Laws and Regulations: Case Study of the Practices of KKN among Indonesian Local Bureaucrats in Districts. Paper presented at the In Search of Middle Indonesia Conference, Leiden, September 27-29.

Riles, Annelise

2001 The Network Inside Out. Ann Arbor: University of Michigan Press.

2006 Documents: Artifacts of Modern Knowledge. Ann Arbor: University of Michigan Press.

Rivkin-Fish, Michelle

2005 Bribes, Gifts, and Unofficial Payments: Rethinking Corruption in Post-Soviet Russian Healthcare. In Corruption: Anthropological Perspectives. Dieter Haller and Cris Shore, eds. Pp. 47-64. Ann Arbor, MI: Pluto Press.

Robison, Richard

2006 Corruption, Collusion and Nepotism after Suharto: Indonesia's Past or Future? International Institute for Asian Studies Newsletter 40:13.

Sampson, Steven

2005 Integrity Warriors: Global Morality and the Anti-Corruption Movement in the Balkans. In Corruption: Anthropological Perspectives. Dieter Haller and Cris Shore, eds. Pp. 103-130. Ann Arbor, MI: Pluto Press.

Sannen, Ad M. H.

1983 Mandors and Tukangs: The Functioning of Informal Subcontractors and Buildingworkers in the Construction Sector of Bandung. Ph.D. dissertation, International Institute of Social Studies, The Hague.

Scott, James C.

1998 Seeing Like a State: How Certain Schemes to Improve the

Human Condition Have Failed. New Haven, CT: Yale University Press.

Shore, Cris

2005 Culture and Corruption in the EU: Reflections on Fraud, Nepotism, and Cronyism in the European Commission. In Corruption: Anthropological Perspectives. Dieter Haller and Cris Shore, eds. Pp. 131-155. Ann Arbor, MI: Pluto Press.

Shore, Cris, and Dieter Haller

2005 Introduction - Sharp Practice: Anthropology and the Study of Corruption. In Corruption: Anthropological Perspectives. Dieter Haller and Cris Shore, eds. Pp. 1-26. Ann Arbor, MI: Pluto Press.

Siegel, James

1998 A New Criminal Type in Jakarta: Counter-Revolution Today. Durham, NC: Duke University Press.
Smith, Daniel Jordan

2006 A Culture of Corruption: Everyday Deception and Popular Discontent in Nigeria. Princeton, NJ: Princeton University Press.

Stansbury, Neill

2005 Exposing the Foundations of Corruption in Construction. In Global Corruption Report 2005. Pp. 36-50. London: Pluto Press and Transparency International. http://archive. transparency.org/publications/gcr/gcr_2005, accessed January 21, 2013.

Strathern, Marilyn

2006 Bullet-Proofing: A Tale from the United Kingdom. In Documents: Artifacts of Modern Knowledge. Annelise Riles, ed. Pp. 181-205. Ann Arbor: University of Michigan Press.

Tarlo, Emma

2001 Paper Truths: The Emergency and Slum Clearance through Forgotten Files. In The Everyday State and Modern India. C. J. Fuller and Véronique Bénei, eds. Pp. 68-90. New Delhi: Social Science Press.

Transparency International 2008 Bribe Payers Index 2008. http://www.transparency.org/ policy_research/surveys_indices/bpi, accessed January $18,2012$.

2009 Global Corruption Report 2009. http://www. transparency.org/publications/gcr/gcr_2009, accessed January 18, 2012.

van Klinken, Gerry, and Edward Aspinall

2011 Building Relations: Corruption, Competition and Cooperation in the Construction Industry. In State and Illegality in Indonesia. Edward Aspinall and Gerry van Klinken, eds. Pp. 139-163. Leiden: Royal Institute of Linguistics and Anthropology Press.

Weber, Max

1968 Max Weber on Charisma and Institution Building: Selected Papers. S. N. Eisenstadt, ed. Chicago: University of Chicago Press.

World Bank

1997 Helping Countries Combat Corruption: The Role of the World Bank. Poverty Reduction and Economic Management. http: / / www1.worldbank.org/publicsector/anticorrupt/ corruptn/coridx.htm, accessed September 15, 2012.

2001 Indonesia; Country Procurement Assessment ReportReforming the Public Procurement System. Jakarta: East Asia and Pacific Region, World Bank Office Jakarta, Operational Service Unit.

Yan, Yunxiang

1996 The Culture of Guanxi in a North China Village. The China Journal 35:1-25.

Yang, Mayfair Mei-hui

1994 Gifts, Favors, and Banquets: The Art of Social Relations in China. Ithaca, NY: Cornell University Press.

Yurchak, Alexei

2006 Everything Was Forever, Until It Was No More: The Last Soviet Generation. Princeton, NJ: Princeton University Press. 